\title{
Differential physiological responses in rice upon exposure to excess distinct iron forms
}

\author{
Caroline Müller • Kacilda Naomi Kuki • Daniel Teixeira Pinheiro • \\ Laíse Rosado de Souza • Advânio Inácio Siqueira Silva • Marcelo Ehlers Loureiro • \\ Marco Antonio Oliva • Andréa Miyasaka Almeida
}

Received: 10 July 2014 / Accepted: 3 February 2015 / Published online: 20 February 2015

(C) The Author(s) 2015. This article is published with open access at Springerlink.com

\begin{abstract}
Background and aims Rice can be cultivated in highlands, which can expose it to iron deficiency, or under irrigation, which can lead to iron toxicity and lower productivity. This study aimed to investigate the strategies used by rice plants under different divalent and trivalent sources of iron excess.

Methods Rice plants from a lowland and upland cultivar were grown in nutrient solution with toxic concentrations of ferrous or ferric iron. A mineral nutrient quantification and anatomical analysis were performed on leaves and roots. Physiological damage was assessed by leaf photochemical parameters and lipid peroxidation. Expression levels of genes related to iron homeostasis were analyzed. Results More pronounced nutritional deficiencies, oxidative stress and physiological damage were observed in plants exposed to toxic levels of ferrous iron. Ferritin expression increased in leaves of both cultivars under ferrous or ferric iron excess.
\end{abstract}

Responsible Editor: Michael A. Grusak.

C. Müller • K. N. Kuki • D. T. Pinheiro • L. R. de Souza •

A. I. Siqueira Silva • M. E. Loureiro • M. A. Oliva •

A. M. Almeida

Departamento de Biologia Vegetal, Universidade Federal de

Viçosa, 36570-000 Viçosa, MG, Brazil

M. A. Oliva

Universidade de Vila Velha, Vila Velha, ES, Brazil

A. M. Almeida $(\bowtie)$

Centro de Biotecnología Vegetal, Universidad Andrés Bello,

República 217, 8370146 Santiago, Chile

e-mail: amiyasaka@unab.cl
Conclusions We showed that sulfate iron was more toxic to the two rice cultivars even though this iron source was less translocated in the plant. Trivalent iron complexed to citrate is easily translocated through rice plants, but it is less toxic than the divalent iron. Rice plants are able to cope with this iron overload by keeping photosynthetic apparatus working properly.

Keywords Oryza sativa Photochemical reactions . Mineral nutrition · Gene expression · Iron toxicity

\begin{tabular}{|c|c|}
\hline \multicolumn{2}{|c|}{ Abbreviations } \\
\hline EDTA & Ethylenediamine tetraacetic acid \\
\hline MDA & Malondialdehyde \\
\hline PSII & Photosystem II \\
\hline$F_{0}$ & Minimal chlorophyll fluorescence \\
\hline$F_{\mathrm{v}} / F_{\mathrm{m}}$ & Maximal photochemical efficiency of PSII \\
\hline $\mathrm{Y}_{\mathrm{II}}$ & $\begin{array}{l}\text { Quantum yield of photochemical energy } \\
\text { conversion in PSII }\end{array}$ \\
\hline qRT-PCR & $\begin{array}{l}\text { Quantitative reverse transcriptase poly- } \\
\text { merase chain reaction }\end{array}$ \\
\hline FER1 & Ferritin \\
\hline$P S B A$ & $\begin{array}{l}\text { Chloroplastic protein Q-B that encodes } \\
\text { PSII reaction center protein D1 }\end{array}$ \\
\hline GS1 & Cytosolic glutamine synthetase \\
\hline$N A S 2$ & Nicotianamine synthetase 2 \\
\hline YSL1 & Yellow stripe-like 1 \\
\hline PII & $\begin{array}{l}\text { Phosphate-limitation Inducible Gene } \underline{1} \text {, a } \\
\text { tonoplast monosaccharide transporter in- } \\
\text { ducible by phosphate } 1 \text { limitation }\end{array}$ \\
\hline PTF1 & $\begin{array}{l}\text { Inducible bHLH by phosphate } 1 \text { limitation } \\
\text { transcription factor }\end{array}$ \\
\hline
\end{tabular}




\section{Introduction}

Rice is an important cereal for human consumption, supplying most of the calories to a large portion of the world's population. Various environmental factors can directly interfere with the productivity of this staple food, including the availability of nutrients. Both a deficiency and an excess of nutrients may equally result in drastic reductions in grain production.

Iron is insoluble and unavailable to most plants because it is mostly present in the soils as trivalent iron oxides (Guerinot and Yi 1994). Rice plants have developed strategies that allow absorption of iron in both divalent $\left(\mathrm{Fe}^{+2}\right)$ and trivalent $\left(\mathrm{Fe}^{+3}\right)$ forms (Bughio et al. 2002; Ishimaru et al. 2006). $\mathrm{Fe}^{+2}$ is soluble and readily available to plants, and it is absorbed by specific transporters (Eide et al. 1996; Yang et al. 2009; Ishimaru et al. 2010). However, $\mathrm{Fe}^{3+}$ ions must be reduced by $\mathrm{Fe}^{+3}$-chelate reductase (Robinson et al. 1999) or complexed to phytosiderophores released by the roots (Higuchi et al. 2001; Bashir et al. 2006; Inoue et al. 2009 ) to be absorbed. This dual character of rice in terms of iron uptake allows the cultivation of this crop in two different systems: under constant flooding or partial periods of water retention in the soil (lowland rice) or in the absence of flooding (upland rice) (Azambuja et al. 2004). In flooded conditions, owing to an anaerobic environment and low $\mathrm{pH}$, iron, initially $\mathrm{Fe}^{3+}$, can be reduced to $\mathrm{Fe}^{2+}$, which, under excess conditions, can reach toxic levels (Bode et al. 1995a; Sahrawat 2005).

Iron toxicity is a complex disorder that can affect different physiological aspects of the plant. Iron excess inside the plant can lead to the enhancement of oxidative stress, as it increases the production of reactive oxygen species (Fang et al. 2001; Majerus et al. 2009), unleashing havoc on most metabolic processes, including photochemical or biochemical obstructions of photosynthesis, with a consequent reduction in the rate of carbon assimilation (Suh et al. 2002; Nenova 2009; Pereira et al. 2013). These biochemical and physiological changes, coupled with sequential nutritional disorders (Olaleye et al. 2001; Onaga et al. 2013) may lead to a loss of productivity (Audebert and Fofana 2009; Chérif et al. 2009; Sahrawat 2010). Also, anatomical alterations, such as the disruption of roots cells and cellular components, are described as results of iron toxicity and undoubtedly affect plant performance (Zhang et al. 2011).
Different mechanisms may confer to rice plants the ability to overcome stress due to iron excess. The formation of an iron plaque, as an exclusion mechanism in the roots of rice plants, can limit the absorption of minerals, such as iron itself (Snowden and Wheeler 1995; Deng et al. 2009). Protection strategies against iron toxicity within the plant may involve enzymatic mechanisms that include the actions of antioxidant enzymes, such as superoxide dismutase, catalase and ascorbate peroxidase (Majerus et al. 2007b; Saikia and Baruah 2012). Non-enzymatic mechanisms can neutralize oxygen reactive species through organic compounds, such as reduced glutathione, $\alpha$-tocopherol, ascorbic acid and carotenoids (Smirnoff 2005). Besides these factors, the compartmentalization of organelles and/or specific proteins is an important step in the metabolism of minerals. Iron storage may occur in the apoplast, vacuoles and plastids, and within the central cavity of a specialized protein known as ferritin (Silveira et al. 2009; Stein et al. 2009a, b; Briat et al. 2010). This macromolecule acts in favor of iron homeostasis in the cells, as observed in rice plants exposed to excess amounts of this metal (Majerus et al. 2009).

In this work the differential responses and sensitivities to iron excess from three iron sources were studied in two rice cultivars. We assessed the effects of iron excess on tissue anatomy, photochemical reactions, absorption and accumulation of nutrients. Further, we investigated the expression of genes involved in iron absorption, transport and homeostasis.

\section{Material and methods}

Plant material, growth conditions and treatments

Rice (Oryza sativa L.) lowland cultivar BR-IRGA 409 (Cordeiro and Medeiros 2008), previously characterized as sensitive to iron excess (SOSBAI 2007), and Canastra (Soares et al. 1997), an upland cultivar which can be cultivated on lowland system, were used in this study. Seeds were sterilized with commercial sodium hypochlorite $(10 \%)$ for $10 \mathrm{~min}$ and germinated in rolled paper towel substrate wetted with distilled water in a growth chamber $\left(27 \pm 2{ }^{\circ} \mathrm{C}\right)$ for 14 days. For the first 7 days the seeds were in the dark, followed by 7 days of a 12-h photoperiod with a light intensity of 200$250 \mu \mathrm{mol} \mathrm{m} \mathrm{m}^{-2} \mathrm{~s}^{-1}$. Seedlings were then transferred to Hoagland nutrient solution ( $\mathrm{pH}$ 4.0, full strength), in 
pots with $3.8 \mathrm{~L}$, without intermittent aeration, under greenhouse conditions. Twenty seedlings per pot were transferred and thinning was performed after 7 days of acclimation leaving only eight seedlings per pot. The Hoagland's nutrient solution used to acclimate the plants and for the control treatments was composed by $1 \mathrm{mM}$ $\mathrm{NH}_{4} \mathrm{H}_{2} \mathrm{PO}_{4}, 6 \mathrm{mM} \mathrm{Ca}\left(\mathrm{NO}_{3}\right)_{2} \bullet 4 \mathrm{H}_{2} \mathrm{O}, 4 \mathrm{mM} \mathrm{KNO}{ }_{3}$, $2 \mathrm{mM} \mathrm{MgSO}{ }_{4} \cdot 7 \mathrm{H}_{2} \mathrm{O}, 46 \mu \mathrm{M} \mathrm{H}_{3} \mathrm{BO}_{3}, 9 \mu \mathrm{M}$ $\mathrm{MnCl}_{2} \bullet 4 \mathrm{H}_{2} \mathrm{O}, 0.78 \mu \mathrm{M} \mathrm{ZnSO} \mathrm{Zn}_{4} \cdot 7 \mathrm{H}_{2} \mathrm{O}, 0.32 \mu \mathrm{M}$ $\mathrm{CuSO}_{4} \cdot 5 \mathrm{H}_{2} \mathrm{O}, 0.14 \mu \mathrm{M} \mathrm{MoO}$ and $18 \mu \mathrm{M} \mathrm{FeSO}_{4}{ }^{-}$ EDTA. After approximately 30 day, plants at the V5 developmental stage (Counce et al. 2000) were exposed to excess amounts of ferrous, $\mathrm{Fe}^{+2}$, or ferric iron, $\mathrm{Fe}^{+3}$, with chelating agents, in a non-aerated hydroponic system. Iron treatments consisted of $7 \mathrm{mM}$ iron sulfate, which was conjugated with ethylenediamine tetraacetic acid (EDTA) (w/w), $7 \mathrm{mM}$ iron chloride and $7 \mathrm{mM}$ iron citrate. These concentrations had been previously determined to be toxic to these cultivars (Pereira et al. 2013). A control treatment consisting of a nutritive solution with chelated iron sulfate at physiological concentrations $\left(0.018 \mathrm{mM} \mathrm{FeSO}_{4}\right.$-EDTA, $\left.5 \mathrm{ppm}\right)$ was conducted in parallel. Each treatment consisted of four replicates, with one pot per replicate. The $\mathrm{pH}$ (4.0) was adjusted every 2 days with $\mathrm{NaOH}$ or $\mathrm{HCl}$, and the complete solution was renewed weekly. Measurements were performed after 7 days of exposure to excess iron, when the temperature was between 24 and $28{ }^{\circ} \mathrm{C}$ and the relative humidity between 53 and $66 \%$ inside the greenhouse.

The iron concentration and speciation in the nutrient solution was calculated using the Visual Minteq software version 3.1 (Gustafsson 2014). The concentration of components of the modified Hoagland solution occupied for each treatment was used as input for the Visual Minteq. The Visual Minteq speciation results showed that the major iron species in each solution corresponded to what was expected for each treatment (Table 1). For the iron sulfate $88.9 \%$ was in $\mathrm{Fe}^{2+}$ complexed to EDTA, for the iron chloride treatment more than $90 \%$ was in the form of $\mathrm{Fe}^{3+}$ complexed to EDTA and for the iron citrate treatment $98 \%$ was in the form of $\mathrm{Fe}^{3+}$ complexed to citrate.

Variables analyzed

\section{Mineral composition}

The concentrations of iron and other nutrients were determined in shoots and roots, after 7 days of exposure to treatments. Prior to the quantification of the nutrient contents of the roots, samples of fresh materials were washed for $70 \mathrm{~min}$ in a dithionite-citrate-bicarbonate solution containing sodium dithionite $(3 \%$, w/v), sodium citrate $(0.3 \mathrm{M})$ and sodium bicarbonate $(1.0 \mathrm{M})$ as described by Liu et al. (2008), to extract possible iron plaque deposits on the root's surface, allowing for the analysis of merely symplastic iron. Then, roots and leaves were dried, ground, digested in concentrated nitric acid $\left(118{ }^{\circ} \mathrm{C}\right.$ for $\left.4 \mathrm{~h}\right)$, diluted in water and analyzed by an inductively coupled plasma mass spectrometry (ICP-MS) according to Lahner et al. (2003). The mineral concentration (mg kg-1) was determined for each of the following elements: iron $(\mathrm{Fe})$, magnesium $(\mathrm{Mg})$, phosphorus $(\mathrm{P})$, sulfur $(\mathrm{S})$, potassium $(\mathrm{K})$, calcium $(\mathrm{Ca})$, boron $(\mathrm{B})$, cobalt $(\mathrm{Co})$, manganese $(\mathrm{Mn})$, nickel $(\mathrm{Ni})$, copper $(\mathrm{Cu})$ and zinc $(\mathrm{Zn})$. The allocation of iron assimilated in the different organs was evaluated according to Bao et al. (2009), as being bioconcentration factor or accumulation in the roots (BCF) and translocation factor $(\mathrm{TF})$ :

$\mathrm{BCF}(\%)=\left[\mathrm{Fe}_{\text {root }} /\left(\mathrm{Fe}_{\text {shoot }}+\mathrm{Fe}_{\text {root }}\right)\right] * 100$ and $\mathrm{T} \mathrm{F}(\%)=\left[\mathrm{Fe}_{\text {shoot }} /\left(\mathrm{Fe}_{\text {shoot }}+\mathrm{Fe}_{\text {root }}\right)\right] * 100$,

where $\mathrm{Fe}_{\text {shoot }}$ and $\mathrm{Fe}_{\text {root }}$ is the iron concentration $\left(\mathrm{mg} \mathrm{Kg}{ }^{-1}\right)$ in shoots and roots, respectively.

\section{Leaf anatomy characterization}

The structural characterization of samples from the leaf blade subapical region (third expanded leaf) was carried out using optical microscopy. Leaf samples were fixed in Karnovsky's solution $(2.5 \%$ glutaraldehyde and $4.0 \%$ paraformaldehyde in sodium cacodylate buffer, $\mathrm{pH} 7.2$, plus $5 \mathrm{mM} \mathrm{CaCl}_{2}$; Karnovsky 1965) for $48 \mathrm{~h}$ and stored in ethanol (70 \%). Subsequently, they were dehydrated in an ethylic series and embedded in hydroxyethyl methacrylate resin (Leica Historesin, Nussloch/Heidelberg, Germany). Transverse sections ( $5 \mu \mathrm{M}$ thick) were made using an automatic rotary microtome (model RM2155, Leica Microsystems Inc. Deerfield, IL, USA) stained with toluidine blue, $\mathrm{pH} 4.0$ (O'Brien et al. 1964) and mounted in Permount. Observations and 
Table 1 Iron chemical species in solutions with different sources of iron as predicted by the MinteqA2 software
Control treatment contained $0.018 \mathrm{mM} \mathrm{FeSO}_{4}$-EDTA and the other treatments contained $7 \mathrm{mM}$ iron in the form indicated. Values are expressed in percent of total iron in solution

\begin{tabular}{|c|c|c|c|c|c|}
\hline \multirow[t]{2}{*}{ Component } & \multirow[t]{2}{*}{ Species name } & \multicolumn{4}{|c|}{ Treatment } \\
\hline & & $\begin{array}{l}\text { Control } \\
\% \text { of tot }\end{array}$ & $\begin{array}{l}\mathrm{FeSO}_{4} \text {-EDTA } \\
\text { oncentration }\end{array}$ & $\mathrm{FeCl}_{3}$-EDTA & Fe-Citrate \\
\hline \multirow[t]{6}{*}{$\mathrm{Fe}^{2+}$} & $\mathrm{Fe}^{+2}$ & 35.00 & 3.63 & - & - \\
\hline & $\mathrm{FeSO}_{4}(\mathrm{aq})$ & 3.30 & 1.26 & - & - \\
\hline & $\mathrm{FeH}_{2} \mathrm{PO}_{4}^{+}$ & 8.55 & 0.74 & - & - \\
\hline & $\mathrm{FeH}_{2} \mathrm{PO}_{4}(\mathrm{aq})$ & 0.04 & - & - & - \\
\hline & FeEDTA $^{-2}$ & 49.73 & 88.97 & - & - \\
\hline & FeHEDTA $^{-}$ & 3.38 & 5.39 & - & - \\
\hline \multirow[t]{11}{*}{$\mathrm{Fe}^{3+}$} & $\mathrm{Fe}^{+3}$ & - & - & 0.013 & - \\
\hline & $\mathrm{FeOH}^{+2}$ & - & - & 0.488 & 0.049 \\
\hline & $\mathrm{Fe}(\mathrm{OH})^{2+}$ & - & - & 0.521 & 0.057 \\
\hline & $\mathrm{FeSO}_{4}^{+}$ & - & - & 0.036 & - \\
\hline & $\mathrm{FeH}_{2} \mathrm{PO}_{4}^{+2}$ & - & - & 0.041 & - \\
\hline & $\mathrm{FeHPO}_{4}^{+}$ & - & - & 6.402 & 1.194 \\
\hline & FeEDTA $^{-}$ & - & - & 92.22 & - \\
\hline & FeHEDTA $^{-}(\mathrm{aq})$ & - & - & 0.246 & - \\
\hline & FeOHEDTA $^{-2}$ & - & - & 0.025 & - \\
\hline & Fe-Citrate (aq) & - & - & - & 98.47 \\
\hline & $\mathrm{FeH}_{-\mathrm{Citrate}^{+}}$ & - & - & - & 0.216 \\
\hline
\end{tabular}

photographic documentation were performed using a photomicroscope (model AX70 TRF, Olympus Optical, Tokyo, Japan) equipped with photo-U system, coupled to a camera (model SPOT Insight color 3.2.0, Diagnostic Instruments Inc., Sterling Heights, MI, USA).

\section{Malondialdehyde (MDA) measurement}

The level of lipid peroxidation was assessed by measuring the MDA concentration (Hodges et al. 1999). MDA was extracted from approximately $160 \mathrm{mg}$ of fresh leaves with $2.0 \mathrm{~mL}$ of trichloroacetic acid (TCA; $0.1 \%)$. After centrifugation $(10000 \times g$ for $15 \mathrm{~min}$ at $4{ }^{\circ} \mathrm{C}$ ), $1.5 \mathrm{~mL}$ of a mixture of thiobarbituric acid (TBA; $0.5 \%)$ and TCA ( $20 \%)$ solutions was added to $500 \mu \mathrm{L}$ of the extract's supernatant. A control for each sample was obtained without the addition of TBA (-TBA). The samples were incubated in a water bath $\left(90{ }^{\circ} \mathrm{C}\right)$ for $20 \mathrm{~min}$, and the reactions were stopped on ice. Absorbance values were read at 440, 532 and $600 \mathrm{~nm}$. The MDA concentration was calculated from the differences in absorbance at 440, 532 and $600 \mathrm{~nm}$ using the extinction coefficient $157 \mathrm{mM}^{-1} \mathrm{~cm}^{-1}$, as shown in the following equations:

$\mathrm{A}=\left(\mathrm{Abs}_{532}+\mathrm{TBA}_{\mathrm{BA}}-\mathrm{Abs}_{600+\mathrm{TBA}}\right)-\left(\mathrm{Abs}_{532}-\mathrm{TBA}-\mathrm{Abs}_{600-\mathrm{TBA}}\right)$,

$\mathrm{B}=\left(\mathrm{Abs}_{400+\mathrm{TBA}}-\mathrm{Abs}_{600+\mathrm{TBA}}\right) \times 0.0571$ and

$\operatorname{MDA}\left(\mathrm{nmol} \mathrm{mL} \mathrm{m}^{-1}\right)=(\mathrm{A}-\mathrm{B} / 157000) \times 106$,

where MDA values were expressed as relative to fresh matter.

\section{Photochemical reactions}

Images of chlorophyll fluorescence were obtained using a Modulated Imaging-PAM fluorometer (Heinz Walz, Effeltrich, Germany). The pixel value images of the fluorescence variables were displayed with the help of a color code ranging from black (0.000) to pink (1.000). For the measurements, leaves were initially darkacclimated so that the reaction centers were fully opened to obtain the minimal $\left(F_{0}\right)$ and maximal chlorophyll fluorescence $\left(F_{\mathrm{m}}\right)$ values; from these, the maximal photosystem II (PSII) quantum yield was calculated $\left(F_{\mathrm{v}} / F_{\mathrm{m}}=\left(F_{\mathrm{m}}-F_{0}\right) / F_{\mathrm{m}}\right)$ (Kitajima and 
Butler 1975). After sample illumination, saturation pulses were applied to determine the light-acclimated maximal fluorescence $\left(F_{\mathrm{m}}{ }^{\prime}\right)$ and the steady-state fluorescence yield $\left(F_{\mathrm{s}}\right)$. From these parameters, it was possible to calculate the quantum yield of photochemical energy conversion in PSII $\left(\mathrm{Y}_{\mathrm{II}}=\left(F_{\mathrm{m}}{ }^{\prime}-F_{\mathrm{s}}\right) / F_{\mathrm{m}}{ }^{\prime}\right)$ according to Genty et al. (1989).

\section{Gene expression}

Total RNA was extracted from fresh leaf materials using homemade TRIzol reagent [38\% phenolic acid (pH 4.5), 0.8 M guanidine thiocyanate, $0.4 \mathrm{M}$ ammonium thiocyanate, $0.1 \mathrm{M}$ sodium acetate ( $\mathrm{pH}$ 5.0), $5.0 \%$ glycerol and diethylpyrocarbonate-treated water] (modified from Chomczynski and Sacchi 1987). After extraction, sodium chloride solution $(150 \mu \mathrm{L}$, $5 \mathrm{~N})$ and chloroform $(450 \mu \mathrm{L})$ were added, and the mixture was centrifuged $(16000 \times g$ for $10 \mathrm{~min}$ at $4{ }^{\circ} \mathrm{C}$ ). RNA was precipitated from the aqueous phase using an equal volume of isopropanol and washed in ethanol (75\%). Total RNA was quantified in a nanocell coupled to a spectrophotometer and analyzed by agarose gel electrophoresis $(0.8 \%$, w/v) stained with GelRed (Biotium ${ }^{\mathrm{TM}}$ ). cDNA synthesis was performed with $2 \mu \mathrm{g}$ of total RNA, pre-treated with DNAse $\left(1 \mu \mathrm{L}, 50 \mathrm{U} \mathrm{LL}^{-1}\right.$, Amplification GradeDNase I, Invitrogen ${ }^{\mathrm{TM}}$ ) and incubated at $37{ }^{\circ} \mathrm{C}$ for $15 \mathrm{~min}$. The first-strand cDNA was synthesized using the kit SuperScript ${ }^{\mathrm{TM}}$ First-Strand Synthesis System for RTPCR (Invitrogen ${ }^{\mathrm{TM}}$ ), in a thermomixer, and stored at $-20{ }^{\circ} \mathrm{C}$.

Four biological replicates with three technical replicates were performed for the quantitative reverse transcriptase polymerase chain reaction (qRTPCR) experiment. Gene expression was analyzed using a StepOnePlus ${ }^{\mathrm{TM}}$ Real-Time PCR System (Applied Biosystems ${ }^{\circledR}$, CA, USA), with a fluorescence detection system for SYBR Green I Mix (Applied Biosystems). The reaction was performed with first-strand cDNA solution $(0.5 \mu \mathrm{L})$, primers (forward and reverse, $10 \mu \mathrm{M}$ each), dNTPs ( $5 \mathrm{mM}), 10 \mathrm{X}$ PCR buffer (Invitrogen), $\mathrm{MgCl}_{2}(50 \mathrm{mM}), \mathrm{SYBR}$ Green I (1:10000; Invitrogen), Platinum Taq DNA polymerase

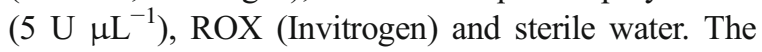
amplification conditions were as follows: hot start at $95^{\circ} \mathrm{C}, 40$ cycles of $95^{\circ} \mathrm{C}$ for denaturation, annealing temperature between 58 and $60{ }^{\circ} \mathrm{C}$, depending on the primer $\mathrm{T}_{\mathrm{m}}$, and an extension temperature of $72{ }^{\circ} \mathrm{C}$. $\mathrm{Ct}$ values were calculated from the values obtained from the fluorescence reactions using Real-time PCR Miner v 2.2 software (Zhao and Fernald 2005; http://www.miner.ewindup.info). The data were normalized to the following housekeeping genes selected from the rice genome using geNorm v. 3.5 software: actin $(O s A C T), \beta$-1,3-glucanase (OsGLU), tubulin (OsTUB4) and ubiquitin_5 (OsUBQ5). The comparative algorithm proposed by Zhao and Fernald (2005) was used to compare RNA transcript abundance. The forward and reverse primer sequences are provided in Table 2.

\section{Statistical analysis}

The experimental design consisted of randomized blocks with four replicates. Differences in MDA concentrations, gas exchange rates, chlorophyll fluorescence levels, mineral concentrations and gene expression were analyzed by ANOVA and Duncan's test, with a $5 \%$ level of significance, using SAS v 9.0 software.

\section{Results}

Differences in planta iron concentrations and translocation rates in response to divalent and trivalent iron sources

A higher iron concentration in the hydroponic solution resulted in higher iron concentrations in rice plants. However, different iron sources had different effects. Use of chelated iron sulfate, resulted in higher root iron concentrations in both cultivars, but higher values were found in the lowland rice cultivar (BR-IRGA 409). No differences in roots' iron concentrations were observed between cultivars when iron chloride and iron citrate were supplied (Fig. 1a). A higher leaf iron concentration in the upland cultivar (Canastra) was observed when iron citrate was used (Fig. 1b and c).

The iron accumulation by the roots, and its translocation to the shoots, represents the allocation of iron assimilated by the different organs (Fig. 1a). Iron translocation was the lowest for both cultivars $(25 \%$ for upland and $17 \%$ for lowland) when iron sulfate was applied. The highest iron translocation rate $(62 \%)$ was observed in the upland cultivar when the rice plants were cultivated in a solution containing iron citrate. 
Table 2 Oryza sativa genes analyzed and corresponding primers

\begin{tabular}{|c|c|c|c|c|}
\hline Genes & GenBank accession numbers & RAP gene ID ${ }^{\mathrm{a}}$ & Fw/Rv 5'-3' Primers & $\operatorname{Tm}\left({ }^{\circ} \mathrm{C}\right) \mathrm{Fw} / \mathrm{Rv}$ \\
\hline OsACT1 & AK105285 & Os04g0177600 & $\begin{array}{l}\text { GGTTCATCAAGAAGGGACCCGG } \\
\text { TGGAGGTGTATCCTGATGCGACAA }\end{array}$ & $57 / 58$ \\
\hline $\begin{array}{l}\text { OsFER1 } \\
\text { OsFER2 }\end{array}$ & $\begin{array}{l}\text { AK059354 } \\
\text { AK102242 }\end{array}$ & $\begin{array}{l}\text { Os11g0106700 } \\
\text { Os12g0106000 }\end{array}$ & $\begin{array}{l}\text { GCACGCAGTAGCAATGGAGTGA } \\
\text { AGCGGCGCCATGTTCCTTTT }\end{array}$ & $58 / 58$ \\
\hline$O s G L U$ & $\begin{array}{l}\text { CI451512 } \\
\text { CI673648 }\end{array}$ & Os04g0450600 & $\begin{array}{l}\text { ATCACATCGGCTACGGTCTT } \\
\text { GGAGGCGACTGAGAAGGTC }\end{array}$ & $53 / 54$ \\
\hline OsGS1 & AK109397 & Os02g0735200 & $\begin{array}{l}\text { TGACGCCACGACATCCTCGT } \\
\text { CAATGGAGCAACCGGAGCGA }\end{array}$ & $58 / 57$ \\
\hline$O s N A S 2$ & AK112011 & Os03g0307200 & $\begin{array}{l}\text { GCTGTGTCTCGCTGTCCGTG } \\
\text { GGCACGGATCAATGCCCAGG }\end{array}$ & $59 / 59$ \\
\hline OsPII & $\begin{array}{l}\text { CI433331 } \\
\text { CI658027 }\end{array}$ & Os01g0838350 & $\begin{array}{l}\text { TCCTCTCTACCCCCAACAATGG } \\
\text { TGGAGAAGGAAGACCTGCCAAA }\end{array}$ & $55 / 56$ \\
\hline$O s P S B A$ & None & Os04g0473150 & $\begin{array}{l}\text { CTGTGGGGTCGCTTCTGCAAC } \\
\text { TACTGGAGGGGCAGCGATGAA }\end{array}$ & $58 / 57$ \\
\hline OsPTF1 & AK065667 & Os06g0193400 & $\begin{array}{l}\text { CGGCTGCAGAAATGTGCTGGA } \\
\text { TGTGCAACAGGCACACAATAGCT }\end{array}$ & $58 / 58$ \\
\hline OsTUB4 & L19598 & Os01g0805900 & $\begin{array}{l}\text { TACCGTGCCCTTACTGTTCC } \\
\text { CGGTGGAATGTCACAGACAC }\end{array}$ & $55 / 55$ \\
\hline OsUBQ5 & AK061988 & Os01g0328400 & $\begin{array}{l}\text { ACCACTTCGACCGCCACTACT } \\
\text { ACGCCTAAGCCTGCTGGTT }\end{array}$ & $57 / 58$ \\
\hline OsYSL1 & AK064828 & Os04g0390500 & $\begin{array}{l}\text { GCTGAAAATAGCGCAAAATCCGTTG } \\
\text { AGTTACTGCACTTTTGCGCAGTC }\end{array}$ & $57 / 57$ \\
\hline
\end{tabular}

${ }^{\mathrm{a}}$ Locus ID number in The Rice Annotation Project database (RAP-DB)

Toxic levels of iron result in morpho-anatomical leaf symptoms and oxidative damage

Visual symptoms of iron toxicity were observed after 3 days of exposure to iron sulfate or iron chloride in both cultivars. The most marked symptom was the bronzing, which initiated at the leaf apex and progressively expanded to the leaf blade mid-region (Fig. 2). After 7 days, both cultivars showed necrosis without visual symptoms of iron toxicity in treatment controls and iron citrate (Fig. 2). By light microscopy, necrotic lesions were more pronounced in leaf blade subapical regions, mainly on the leaf edges of plants receiving the iron sulfate treatment (Fig. 3b and d) for both cultivars. Iron toxicity was linked to the collapse of epidermal and mesophyll cells, resulting in a reduced leaf blade thickness (Fig. $3 b$ and d). The leaves of control plants (both cultivars) presented normal tissues (Fig. 3a and c).

Lipid oxidation in leaves was evaluated by quantifying MDA. The treatments with iron sulfate and iron chloride led to an average increase of $134 \%$ (38.1 $\mathrm{nmol} \mathrm{mg}^{-1} \mathrm{gFW}$; Fig. 4b) in the MDA concentrations of leaves from both upland and lowland cultivars compared with control plants. In roots, the highest MDA concentration was achieved in both cultivars when plants were treated with iron citrate (9.9 $\mathrm{nmol} \mathrm{mg}^{-1}$ gFW; Fig. 4a).

High levels of iron affect photochemical reactions

Both rice cultivars showed a reduction in the $\mathrm{Y}_{\mathrm{II}}$ in PSII under high iron levels. The reductions were more pronounced (up to $57 \%$ ) in the upland cultivar exposed to a high concentration of iron sulfate (Fig. 5c). Reductions were observed in the lowland cultivar only when excess iron sulfate $(31 \%)$ or iron chloride (41\%) was supplied (Fig. 5c). No changes were observed in $\mathrm{F}_{0}$ or $\mathrm{F}_{\mathrm{v}} / \mathrm{F}_{\mathrm{m}}$ of either cultivar (Fig. $5 \mathrm{a}$ and $\mathrm{b}$ ).

Iron source impacts nutrient concentrations of rice plants although subordinate to the cultivar

Iron excess in hydroponic solution affected only leaf $\mathrm{Ca}$ and $\mathrm{Mg}$ concentrations and not their levels in roots 

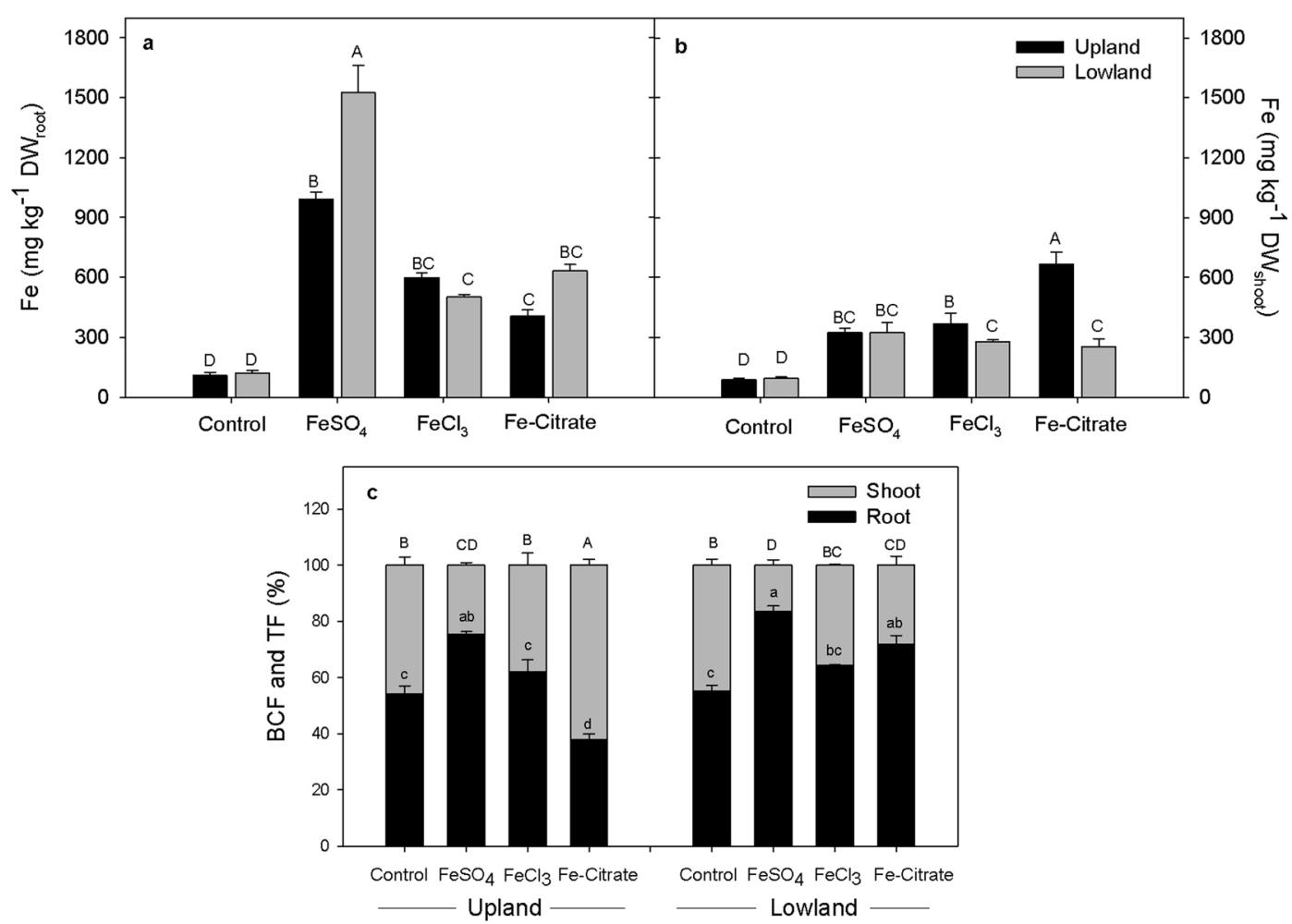

Fig. 1 Iron concentrations in roots (a) and in leaves (b) and iron uptake by roots $(\mathbf{c}, \mathbf{C})$ and iron translocation factor to shoots (c, $\square$ ) of the Oryza sativa L. upland cultivar (Canastra) and lowland cultivar (BR-IRGA 409), after 7 days exposure to different sources of iron $(7 \mathrm{mM})$ or to $0.018 \mathrm{mM}$ iron sulfate $\left(\mathrm{FeSO}_{4}\right.$-EDTA,

control) in a hydroponic system. Data are presented as the means \pm SE. Means followed by the same letter do not differ significantly from each other, as determined by Duncan's test $(p \geq 0.05)$

(Fig. 6a and c). Ca concentrations in leaves were reduced, under iron sulfate and iron citrate treatments, by approximately $27 \%$ in both cultivars (Fig. 6a). Leaf Mg levels were reduced by $26 \%$ in both cultivars when iron sulfate was applied (Fig. 6c). The root concentration of $\mathrm{K}$ decreased at a high iron dosage in both cultivars; however, the decrease was more pronounced when iron sulfate was applied (Fig. 6b). No effects on leaf K concentrations were observed in any treatment (Fig. 6b). P concentrations were reduced (25\%) in roots

of the lowland cultivar under iron chloride supply (Fig. 6d). However, in leaves, lower P concentrations (40 and $50 \%$ ) and $\mathrm{Mn}$ (43 and $54 \%$ ) were observed in the upland and lowland cultivars, respectively (Fig. $6 \mathrm{~d}$ and $g$ ), with all iron sources. An incremental increase in Co concentrations was observed in both cultivars, reaching approximately $200 \%$ in roots of plants exposed to ferric iron forms (iron chloride and iron citrate; Fig. 6e). In leaves, Co concentrations increased in both cultivars (Fig. 6e) in response to iron chloride (38\% in
Fig. 2 Oryza sativa L. leaves from the upland cultivar (Canastra) and lowland cultivar (BR-IRGA 409), after 7 days exposure to different sources of iron $(7 \mathrm{mM})$ or to $0.018 \mathrm{mM}$ iron sulfate $\left(\mathrm{FeSO}_{4}\right.$-EDTA, control) in a hydroponic system

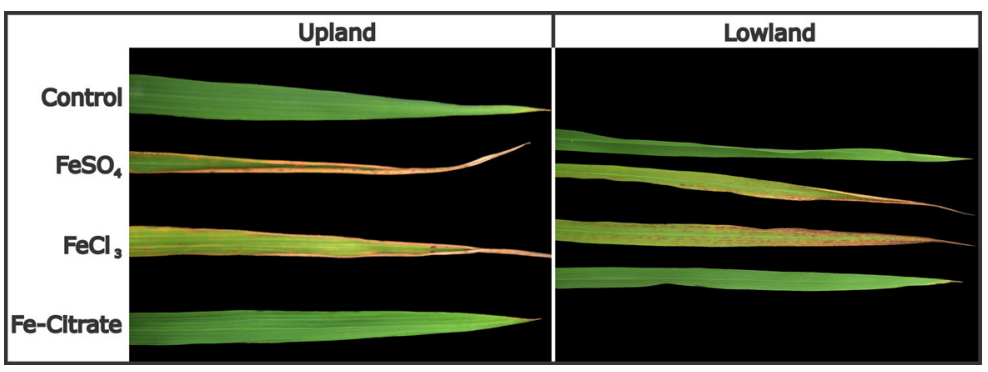




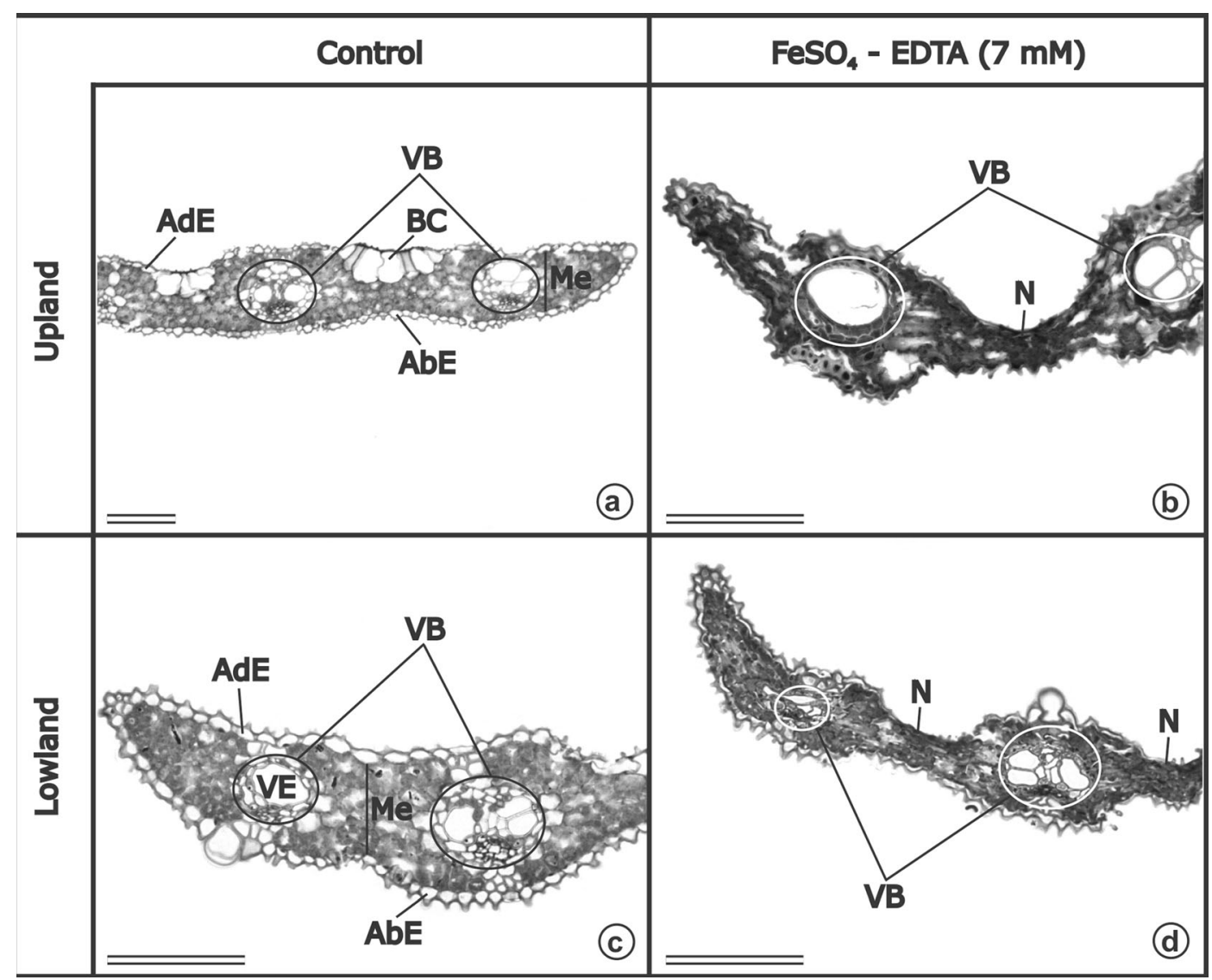

Fig. 3 Leaf blade of Oryza sativa L. upland cultivar, Canastra (a and b) and lowland cultivar, BR-IRGA 409 (c and d), in transverse sections (light microscopy). Control treatment (a and c). Treatment with iron excess (b and $\mathbf{d}$ ), after culturing 7 days in a nutrient solution containing $\mathrm{FeSO}_{4}$-EDTA $(7 \mathrm{mM})$. a and c Whole leaf border. b and d Necrotic leaf border. Legend: $A d E$ adaxial leaf surface, $A b E$ abaxial leaf surface, $V B$ vascular bundle, $B C$ bulliform cell, $M e$ mesophyll, $V E$ vessel element, and $N$ necrotic tissue. Bars: $100 \mu \mathrm{m}(\mathbf{a}-\mathbf{d})$

chloride excess (Fig. 6f). In leaves, an increase of $67 \%$, on average, in the $\mathrm{Cu}$ concentration was observed in both cultivars exposed to iron chloride (Fig. 6f). The Zn concentration was marginally increased in roots $(20 \%)$,
Canastra and $64 \%$ in BR-IRGA 409) and iron citrate (around $125 \%$ for both cultivars). Cu concentrations in roots increased 535 and $342 \%$ (in plants from the upland and lowland cultivars, respectively, under iron

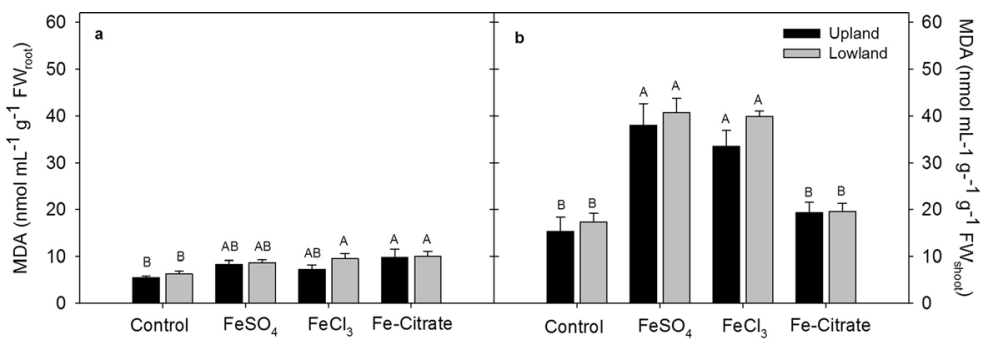

Fig. 4 Malondialdehyde (MDA) levels in roots (a) and leaves (b) of the Oryza sativa L. upland cultivar (Canastra) and lowland cultivar (BR-IRGA 409), after 7 days exposure to different sources of iron $(7 \mathrm{mM})$ or to $0.018 \mathrm{mM}$ iron sulfate $\left(\mathrm{FeSO}_{4}\right.$-EDTA, control) in a hydroponic system. Data are presented as the means \pm SE. Means followed by the same letter do not differ significantly from each other, as determined by Duncan's test $(p \geq 0.05)$ 

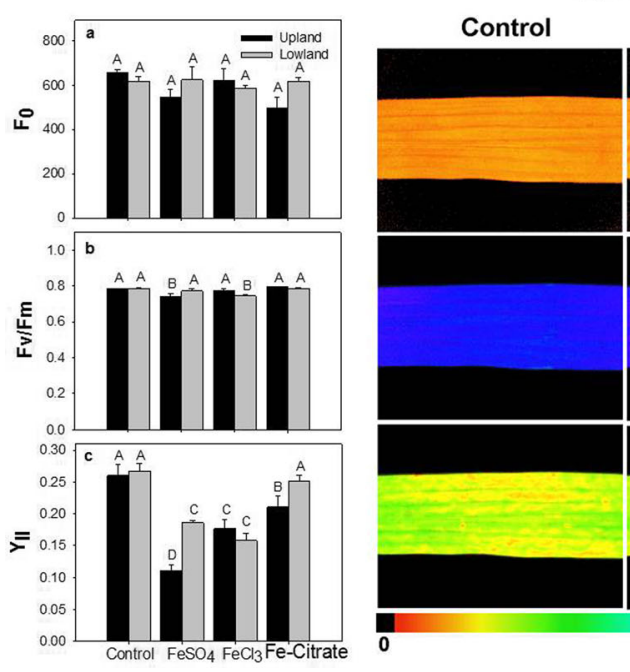

Fig. 5 Minimal fluorescence $\left(\mathrm{F}_{0} ; \mathbf{a}\right)$, maximal PSII quantum yield $\left(\mathrm{F}_{\mathrm{v}} / \mathrm{F}_{\mathrm{m}} ; \mathbf{b}\right)$ and quantum yield of photochemical energy conversion in PSII (Y $\mathrm{Y}_{\mathrm{II}}$; c) of the Oryza sativa L. upland cultivar (Canastra) and lowland cultivar (BR-IRGA 409), after 7 days exposure to different sources of iron $(7 \mathrm{mM})$ or to $0.018 \mathrm{mM}$ iron sulfate

but only in the lowland cultivar grown under iron sulfate excess (Fig. 6h). However, iron citrate led to a decrease $(18 \%)$ in the $\mathrm{Zn}$ concentration in the roots of the same cultivar. In leaves, the $\mathrm{Zn}$ concentration increased $(37 \%)$ only in the upland cultivar when iron sulfate was supplied (Fig. 6h).

Iron excess affects the relative expression of different genes

The relative expression of the genes that encodes ferritin (OSFER1 and OSFER2), protein responsible for the storage of iron, increased in the lowland cultivar in all treatments (up to 70-fold, Table 3). The primers used in this work matched for the two ferritin genes present in rice genome (Stein et al. 2009b). Expression of these same genes in the upland cultivar increased by 46-fold when plants were grown in iron sulfate, 30 -fold when grown in the presence of iron chloride and 18-fold in the presence of iron citrate, compared with the respective control. Expression of $O s P s b A$, which encodes protein D1 in PSII, increased up to 2.6-fold in both cultivars when the plants were treated with iron sulfate and iron citrate (Table 3). Expression of the gene that encodes glutamate synthase (OsGS1), an enzyme related to photorespiration in plants, increased in the upland cultivar (3.8-fold) and lowland cultivar (2.6-fold) when treated
Lowland

$\mathrm{FeSO}_{4}$-EDTA

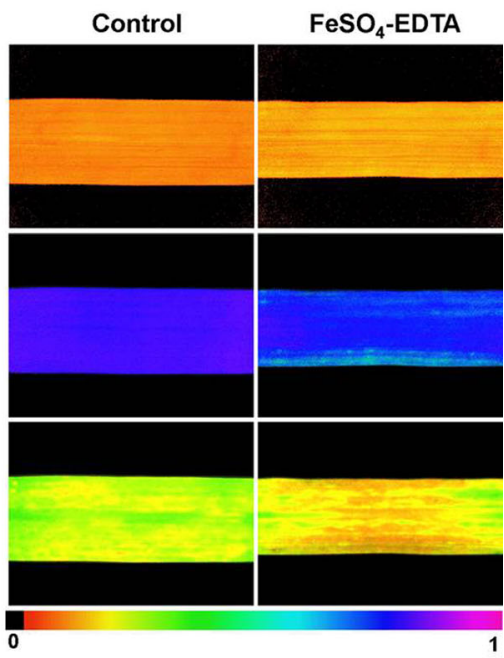

( $\mathrm{FeSO}_{4}$-EDTA, control) in a hydroponic system. Data are presented as the means \pm SE. Means followed by the same letter do not differ significantly from each other, as determined by Duncan's test $(p \geq 0.05)$. The false color code depicted at the bottom of images ranges from 0.0 (black) to 1.0 (pink)

with a high level of iron sulfate. Expression of the same gene increased by 5.5 -fold in plants from the lowland cultivar exposed to excess iron chloride. The gene expression of transporters was differentially affected in rice plants grown in iron excess. The expression of nicotianamine synthetase, OsNAS2, necessary for the biosynthesis of phytosiderophores (PS), was higher in the control treatment than under the different iron excess treatments in the upland rice cultivar (Table 3). Expression of this gene was increased in the lowland cultivar treated with iron sulfate (2.6-fold), iron chloride (2.9-fold) and iron citrate (1.8-fold), compared with the control. The gene expression of Yellow Stripe-Like 1, OsYSL1, a transporter of Fe-PS, increased 3.4- and 2.1fold in the upland cultivar grown in iron sulfate and iron citrate, respectively. The lowland cultivar had a 2.2-fold increase in OSYSL1 expression when the plants were treated with iron sulfate or iron chloride. The relative gene expression of the Phosphate-limitation Inducible Gene 1 (OsPI1), a phosphorus transporter, was increased 2.1- and 1.8-fold under the iron sulfate treatment in the lowland and upland cultivars, respectively (Table 2). There were changes in expression of the phosphate 1 limitation transcription factor OSPTF1, which is involved in tolerance to inorganic phosphate (Pi) starvation, only in the upland rice cultivar grown under iron sulfate excess. 


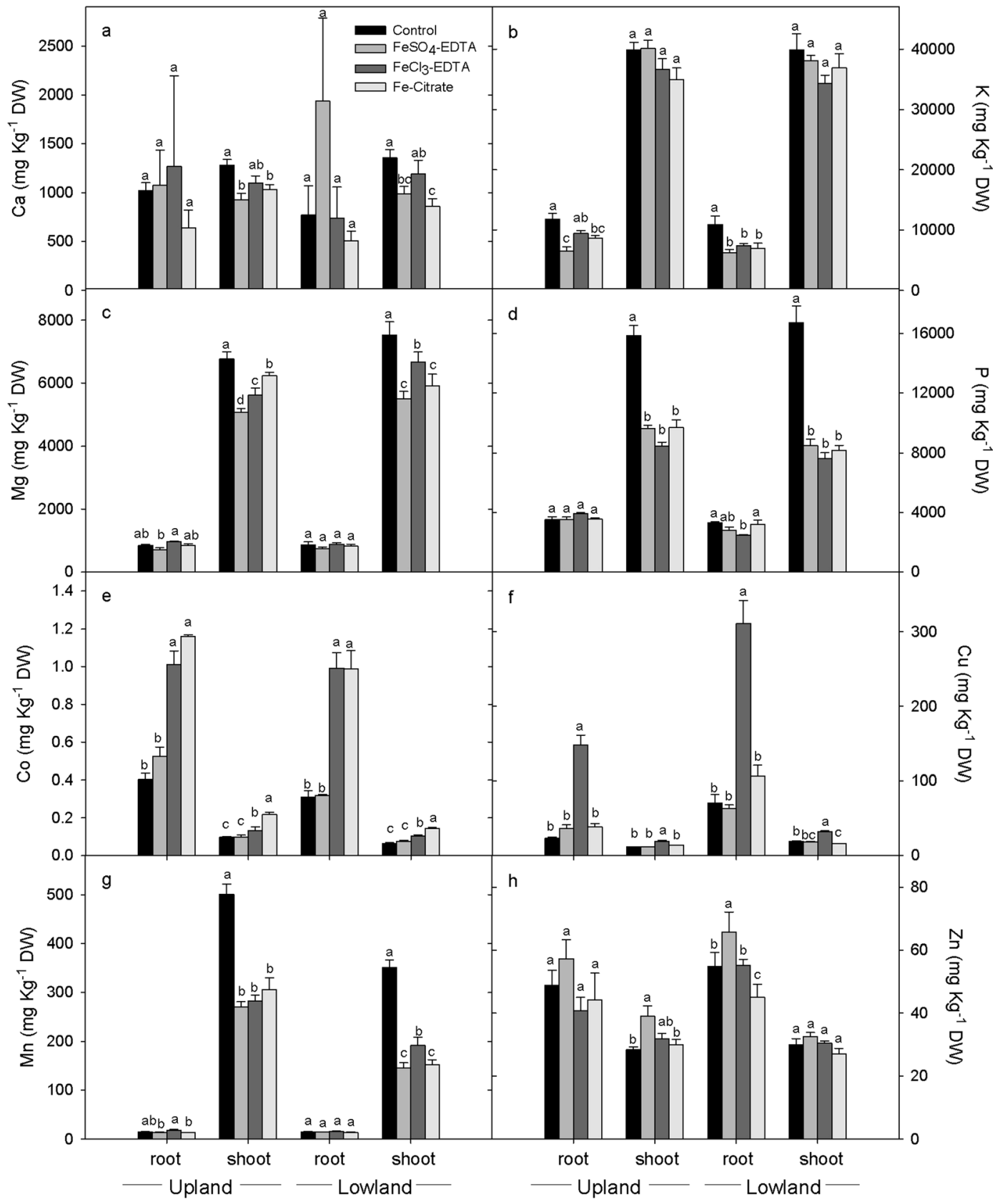

Fig. 6 Mineral nutrient concentration ( $\left.\mathrm{mg} \mathrm{kg}^{-1} \mathrm{DW}\right)$ of roots and shoots of the Oryza sativa L. upland cultivar (Canastra) and lowland cultivar (BR-IRGA 409), after 7 days exposure to different sources of iron $(7 \mathrm{mM})$ or to $0.018 \mathrm{mM}$ iron sulfate $\left(\mathrm{FeSO}_{4}\right.$ -

EDTA, control) in a hydroponic system. Data are presented as the means \pm SE. Means followed by the same letter do not differ significantly from each other, as determined by Duncan's test $(p \geq 0.05)$

\section{Discussion}

Iron excess caused morphological, anatomical and physiological changes in plants of the upland and lowland rice cultivars. The effects were visually observed as

the bronzing of leaves from the third day of treatment (Fig. 2). The bronzing is caused by an increase in polyphenol content, which is normally oxidized in leaves with high levels of iron above $300 \mathrm{mg} \mathrm{kg}^{-1}$ DW (Tanaka et al. 1966; Mehraban 
Table 3 qRT-PCR analysis on mRNA relative level (fold) of the genes: ferritin $(O s F E R)$, protein chloroplastic Q-B (OsPsbA), cytosolic glutamine synthetase $(O s G S 1)$, nicotianamine synthetase (OsNAS2), Yellow Stripe Like 1 (OsYSL1), tonoplast monosaccharide transporter inducible by phosphate 1 limitation (OsPII), inducible bHLH by phosphate 1 limitation transcription factor $(O S P T F 1)$, in leaves of a rice upland cultivar (Canastra) and a lowland cultivar (BR-IRGA 409), after 7 days of exposure to different sources of iron $(7 \mathrm{mM})$ or to $0.019 \mathrm{mM}\left(\mathrm{FeSO}_{4}\right.$-EDTA, control) in nutrient solution

\begin{tabular}{lllllllll}
\hline Cultivar & Iron source & OsFER & OsPsbA & OsGS1 & OsNAS2 & OsYSL1 & OsPI1 & OsPTF1 \\
\hline Upland (Canastra) & Control & $1.00 \mathrm{~d}$ & $1.00 \mathrm{e}$ & $1.00 \mathrm{e}$ & $1.00 \mathrm{a}$ & $1.00 \mathrm{c}$ & $1.00 \mathrm{bc}$ & $1.00 \mathrm{a}$ \\
& FeSO $_{4}$ & $46.15 \mathrm{a}$ & $1.53 \mathrm{cde}$ & $3.75 \mathrm{c}$ & $0.30 \mathrm{~b}$ & $3.38 \mathrm{ab}$ & $1.80 \mathrm{a}$ & $0.33 \mathrm{~b}$ \\
& $\mathrm{FeCl}_{3}$ & $29.67 \mathrm{bc}$ & $1.23 \mathrm{de}$ & $2.89 \mathrm{~cd}$ & $0.15 \mathrm{c}$ & $1.18 \mathrm{c}$ & $0.97 \mathrm{bc}$ & $0.64 \mathrm{ab}$ \\
& $\mathrm{Fe}-C i t r a t e^{2}$ & $17.62 \mathrm{c}$ & $2.56 \mathrm{bc}$ & $1.31 \mathrm{de}$ & $0.10 \mathrm{c}$ & $2.06 \mathrm{bc}$ & $1.27 \mathrm{abc}$ & $0.74 \mathrm{ab}$ \\
& $\mathrm{Control}_{\text {Lowland (BR-IRGA 409) }}$ & $1.00 \mathrm{~d}$ & $1.00 \mathrm{de}$ & $1.00 \mathrm{cde}$ & $1.00 \mathrm{c}$ & $1.00 \mathrm{bc}$ & $1.00 \mathrm{c}$ & $1.00 \mathrm{ab}$ \\
& $\mathrm{FeSO}_{4}$ & $63.68 \mathrm{ab}$ & $1.58 \mathrm{bcd}$ & $2.63 \mathrm{~b}$ & $2.57 \mathrm{~b}$ & $2.17 \mathrm{a}$ & $2.07 \mathrm{a}$ & $1.44 \mathrm{ab}$ \\
& $\mathrm{FeCl}_{3}$ & $77.37 \mathrm{a}$ & $2.61 \mathrm{a}$ & $5.56 \mathrm{a}$ & $2.87 \mathrm{~b}$ & $2.28 \mathrm{a}$ & $1.66 \mathrm{abc}$ & $1.35 \mathrm{ab}$ \\
& $\mathrm{Fe}-C i t r a t e^{2}$ & $67.50 \mathrm{ab}$ & $2.14 \mathrm{ab}$ & $1.48 \mathrm{c}$ & $1.83 \mathrm{bc}$ & $0.85 \mathrm{c}$ & $1.80 \mathrm{ab}$ & $0.67 \mathrm{ab}$ \\
\hline
\end{tabular}

Relative levels of gene expression (fold changes) normalized to the expression levels of the housekeeping genes ubiquitin_5 (OsUBQ5) and tubulin (OsTUB4). Means followed by the same letter were grouped by the Duncan test. The data are presented as the fold change compared with the control from the corresponding cultivar. Fold values were derived from averages of four biological and three technical replicates

et al. 2008; Saikia and Baruah 2012), as observed in this study in all treatments (Fig. 1). Plants treated with iron-citrate did not show visual symptoms at the end of the treatment indicating that this complex can be better metabolized.

The high iron accumulation in roots of both rice cultivars grown with excess of iron sulfate (Fig. 1a) may be due to the maintenance of solubility and availability of iron in its divalent form (Fang et al. 2001; Sahrawat 2005). The addition of EDTA may have also favored the bioavailability by minimizing reoxidation of iron and iron plaque formation (Taylor et al. 1984; Snowden and Wheeler 1995). Indeed, iron plaque formation was induced in Brazilian upland and lowland cultivars when iron sulfate was provided without the use of the chelating agent (Pereira et al. 2014). Unfortunately in this work we did not measured iron plaque formation.

Rice plants cultivated with iron chloride excess had lower levels of iron accumulation in roots than plants from the iron sulfate treatment (Fig. 1a). This may be because $\mathrm{Fe}^{+3}$ requires the reduction or complexation of the metal ions into phytosiderophores, as mugenic acid, to enable iron uptake (Bashir et al. 2006; Ishimaru et al. 2006). Conversely, $\mathrm{Co}$ and $\mathrm{Cu}$ showed an increase in rice plants exposed to trivalent iron form sources (Figs. 6e and 6f). The $\mathrm{Fe}^{+3}$-mugenic acid complex is structurally analogous to the $\mathrm{Co}^{+3}$ complex (Mino et al. 1983). A possible increase in the synthesis of mugineic acid and other phytosiderophores due to $\mathrm{Fe}^{+3}$ excess treatment could favor $\mathrm{Co}^{+3}$ uptake. In fact, an upregulation of OsNAS2 gene expression that codifies for an enzyme of phytosiderophore biosynthetic pathway was observed in the lowland rice cultivar treated with excess of iron chloride and iron citrate (Table 3). Previous studies had shown that the expression of genes related to phytosiderophore biosynthetic pathway remains constant or decreases in response to iron excess, in contrast to genes related to the transport of metal-phytosiderophore complexes that are upregulated which could be the case for the upland cultivar (Quinet et al. 2012). On the other hand, the copper $\mathrm{Cu}$ and $\mathrm{Fe}$ share the same plasma-membrane reductase system (Mukherjee et al. 2006), which can generate synergy in the absorption of $\mathrm{Fe}$ and $\mathrm{Cu}$ by plants grown with excess $\mathrm{Fe}^{+3}$. Regarding the sources of trivalent iron, however, the application of ferric chloride promoted a sharp increase in the copper content of the roots, which can be explained by ferric chloride solubilizes copper (Khandpur 2005), promoting its absorption.

The highest level of iron translocation to shoots of rice plants was observed when iron was provided in the iron-citrate complex (Fig. 1c). This iron form is immediately available because rice roots possess citrate transporters necessary for the translocation of iron-citrate directly to the shoots (Cataldo et al. 1988; Yokosho et al. 2009). However, it is interesting to note that despite the increased translocation of iron, this condition 
was less toxic than the others. The high iron accumulation associated with a high biomass production indicates a tissue tolerance mechanism (Elec et al. 2013). In other experiments using iron sulfate in similar concentrations but in the absence of chelators it was observed much higher shoot iron concentrations than in our conditions (Pereira et al. 2014; Wu et al. 2014). In our experiments EDTA was used as an iron chelator preventing its precipitation in the nutrient solution. Due to the differences in iron shoot concentrations observed, probably EDTA maintain iron in a more stable form in solution being more difficult for rice roots to mobilize and absorb the mineral. The lowest MDA concentrations and highest $\mathrm{Y}_{\mathrm{II}}$ in PSII were observed under this condition (Figs. $4 \mathrm{~b}$ and $5 \mathrm{c}$ ). Some rice genotypes are able to accumulate high iron levels in leaves without showing leaf toxicity symptoms (Asch et al. 2005; Stein et al. 2009a; Engel et al. 2012). This may occur because the plants can oxidize the large amounts of iron translocated to shoots. This oxidation occurs after iron is released from chelator molecules in the apoplast, preventing its entry into the symplast, as a possible exclusion mechanism (Majerus et al. 2007a; Engel 2009). Alternatively, intracellular iron may be incorporated into organic compounds, such as the protein ferritin (Silveira et al. 2009). The increase in the expression level of OsFER was observed in both cultivars tested in this work, indicating that this biochemical mechanism for counteracting iron toxicity was not cultivar specific (Table 3 ). Although the primers used in this work matched for the two ferritin genes present in rice genome, the transcript increase observed is probably from OSFER2 that was previously reported to be responsive to iron excess (Stein et al. 2009b). The scavenging action of ferritin also plays an important role in plant defenses against oxidative stress induced by iron, preventing the metal's reaction with oxygen (Majerus et al. 2009; Briat et al. 2010).

The accumulation of various nutrients in leaves was affected by excess iron in the solution. This was previously observed in other studies and the degree of mineral nutrient variation may depend on iron dosage, time of exposure, developmental stage and genotype (Dorlodot et al. 2005; Pereira et al. 2014; Silveira et al. 2007). However this is the first time that different types of iron sources are evaluated. We observed that accumulation of $\mathrm{P}$ and $\mathrm{Mn}$ was significantly reduced in rice plants, regardless of the sources of iron or the cultivar evaluated (Fig. 6d and g). The decrease in Mn levels in leaves when under iron excess may be linked to the antagonistic effects between these elements (Tanaka and Navasero 1966). Since Mn is required in PSII (Brudvig 1987), this nutrient deficiency can affect photosynthetic processes in rice plants. Consequently, the symptoms of Mn deficiency correspond to the symptoms of iron toxicity (Somers and Shive 1942). Decreases in $\mathrm{P}$ concentrations in leaves of rice grown under iron excess have also been reported, suggesting that there is a limitation in the uptake of $\mathrm{P}$ from the root apoplast to the symplast under this condition, which results in limited translocation to shoots (Silveira et al. 2007). In fact, large amounts of iron oxides that accumulate in the roots, as part of the iron root plaque, strongly interact with $\mathrm{P}$, and the iron plaque on the rice roots can be considered a $\mathrm{P}$ reservoir (Zhang et al. 1999). The increase in OSPI1 and OsPTF1 expression, which are, respectively a $P$ transporter and a transcription factor related to $\mathrm{P}$ starvation (Table 3), also indicates that excess iron is affecting P nutrition.

Iron excess in leaf tissues caused prominent morphoanatomical changes in the rice leaves. The leaf bronzing observed in both cultivars studied is a classic symptom of iron toxicity (Engel et al. 2012; Santana et al. 2014). Cellular collapse due to injuries of the epidermal and mesophyll cells, and the reduction in the thickness of leaf blade (Fig. 3), were followed by foliar necrosis (Fig. 2). These symptoms, which are indicative of oxidative stress in leaves (Peng and Yamauchi 1993; Bode et al. 1995b; Engel et al. 2012), occurred markedly in plants treated with iron sulfate or iron chloride. The severe stress can cause a cellular imbalance in favor of pro-oxidants to the detriment of antioxidants, triggering oxidative stress, as confirmed by the high concentration of MDA in leaves of rice grown under an excess of iron sulfate or iron chloride (Fig. 4b). Thus, intrinsic antioxidant defense systems can also be important factors in the resistance to toxicity (Suh et al. 2002). The ironcitrate complex, supplied in one of the treatments, may have contributed to a lower availability of free iron to react with reactive oxygen species and to promote oxidative stress in both cultivars (Fig. 4b). Plants from the upland cultivar, when cultivated under flooded conditions, did not exhibit a potential exclusion mechanism for iron-citrate and allowed for greater iron accumulation in leaves (Fig. 1b). Despite the high iron concentration in leaves, MDA levels were low in these plants. These results suggest that mechanisms to prevent cellular damage as iron cellular compartmentalization were at play. 
The $\mathrm{Y}_{\text {II }}$ in PSII in rice plants was also affected by iron excess in the nutrient solutions. $Y_{I I}$ is of crucial importance in plants and is highly sensitive to stresses. The upland cultivar showed a more drastic decrease in $Y_{\text {II }}$ than the lowland cultivar, when exposed to iron sulfate (Fig. 5c). The reduction in $\mathrm{Y}_{\mathrm{II}}$ may have been due to the oxidation of constituents of the photosynthetic complexes, such as psbA protein (D1) present in PSII. The greater increase in expression of the OsPsbA gene in the lowland cultivar (Table 3 ) suggests a possible protective mechanism of regeneration and repair, since the psbA protein is a critical component for the functionality of PSII (Bhagwat and Bhattacharjee 2005).

In addition to photochemical electron dissipation, other cellular processes have alternative actions in the dissipation of excess energy under stress conditions, including the water-water cycle (Asada 2000; Weng et al. 2007) or cyclic electron flow (Makino et al. 2002), the maintenance of electron transport in alternative ways and photorespiration (Wingler et al. 2000), which avoids the formation of reactive oxygen species once reducing power is consumed. The increase in expression of the $O s G S 1$ gene has a key role in photorespiration (Oliveira et al. 2012) and may indicate a protective mechanism in both cultivars under iron stress. Gene expression of the cytosolic glutamine synthetase increased in both cultivars; however, it was more pronounced in the lowland cultivar (Table 3), which may indicate an attempt to avoid and/or minimize the more severe damage observed by the higher level of lipid peroxidation (Fig. 4) and $\mathrm{Y}_{\mathrm{II}}$ reduction (Fig. 5c). Increased expression of $\mathrm{OSGSl}$, which was less pronounced in the upland cultivar, may have been due to another mechanism for efficient energy dissipation in these plants. $\mathrm{Y}_{\mathrm{II}}$ is also competitive with other processes that can act in non-photochemical dissipation and may occur to minimize the damage caused by iron, such as thermal energy dissipation by the xanthophyll cycle (Wilson et al. 2007; Pereira et al. 2013). Similar findings were also revealed by the imaging of the fluorescence parameters, indicating that the $\mathrm{Y}_{\mathrm{II}}$ in PSII was the most susceptible parameter, especially under the iron sulfate treatment.

We showed in this work that the divalent iron source was more toxic to the two rice cultivars even though the iron source was translocated to a lesser degree in the plant. When the plants were treated with this iron source, the photosynthetic parameters decreased the most. Despite the toxicity to both cultivars, the levels of accumulation in roots and the translocation of iron were different among the sources of iron evaluated. Under cultivation with ferrous sulfate, the symplastic iron was mainly accumulated in the roots of rice plants. This can be considered an exclusion mechanism. The iron citrate however, was highly translocated to the shoots in the upland cultivar but still showed a lower toxicity compared with ferrous sulfate, which indicates an internal tolerance mechanism to iron excess in the shoots. The upland cultivar was more sensitive to excess iron under anaerobic conditions than the lowland cultivar. This study shows that even though ferrous sulfate showed a greater toxicity in both cultivars in relation to sources of trivalent iron, different cultivars may also present different mechanisms to deal with excess iron. This differential response of Brazilian lowland and upland rice cultivars to iron excess is currently being assessed in our laboratory.

Acknowledgments The authors thank the Empresa Brasileira de Pesquisa Agropecuária (EMBRAPA) and the Empresa de Pesquisa Agropecuária de Minas Gerais (EPAMIG) for providing rice seeds. This work was supported by the Coordenação de Aperfeioçamento de Pessoal de Nível Superior-PROCAD/ CAPES (grant no. 0361054/2005 to M.A.O) and the Fundação de Amparo a Pesquisa do Estado de Minas Gerais-FAPEMIG (grant no. APQ-1011-3.08/07 to A.M.A.), Brazil. The authors also thank Dr. David Salt for the ICP-MS analysis of rice tissues. C.M., D.T.P., L.R.S. and A.I.S.S. and C.H.S. are grateful to the CNPq and to FAPEMIG for scholarships.

Open Access This article is distributed under the terms of the Creative Commons Attribution License which permits any use, distribution, and reproduction in any medium, provided the original author(s) and the source are credited.

\section{References}

Asada K (2000) The water-water cycle as alternative photon and electron sinks. Philos Trans R Soc B 355:1419-1431. doi: $10.1098 /$ rstb.2000.0703

Asch F, Becker M, Kpongor DS (2005) A quick and efficient screen for resistance to iron toxicity in lowland rice. J Plant Nutr Soil Sci 168:764-773. doi:10.1002/jpln.200520540

Audebert A, Fofana M (2009) Rice yield gap due to iron toxicity in West Africa. J Agron Crop Sci 195:66-76. doi:10.1111/j. 1439-037X.2008.00339.x

Azambuja IHV, Venetti JFJ, Magalhães JAM (2004) Aspectos socioeconômicos da produção de arroz. In: Gomes AS, Magalhães JAM (eds) Arroz Irrigado no Sul do Brasil, 1st edn. Embrapa, Brasília, pp 23-44

Bao T, Sun L, Sun T, Zhang P, Niu Z (2009) Iron-deficiency induces cadmium uptake and accumulation in Solanum 
nigrum L. Bull Environ Contam Toxicol 82:338-342. doi:10.1007/s00128-008-9573-8

Bashir K, Inoue H, Nagasaka S, Takahashi M, Nakanishi H, Mori S, Nishizawa NK (2006) Cloning and characterization of deoxymugineic acid synthase genes from graminaceous plants. J Biol Chem 281:32395-32402. doi:10.1074/jbc. M604133200

Bhagwat AS, Bhattacharjee SK (2005) Thermoluminescence as a tool in the study of photosynthesis. In: Pessarakli M (ed) Handbook of photosynthesis, 2nd edn. CRC Press, Florida, pp 21-36. doi:10.1201/9781420027877.ch2

Bode K, Döring O, Lüthje S, Böttger M (1995a) Induction of iron toxicity symptoms in rice (Oryza sativa L.). Mitt Inst Allg Bot Hamburg 25:35-43

Bode K, Döring O, Lüthje S, Neue HU, Böttger M (1995b) The role of active oxygen in iron tolerance of rice (Oryza sativa L.). Protoplasma 184:249-255. doi:10.1007/BF01276928

Briat JF, Ravet K, Arnaud N, Duc C, Boucherez J, Touraine B, Cellier F, Gaymard F (2010) New insights into ferritin synthesis and function highlight a link between iron homeostasis and oxidative stress in plants. Ann Bot 105: 811-822. doi:10.1093/aob/mcp128

Brudvig GW (1987) The tetranuclear manganese complex of Photosystem II. J Bioenerg Biomembr 19:91-104. doi:10.1007/BF00762719

Bughio N, Yamaguchi H, Nishizawa NK, Nakanishi H, Mori S (2002) Cloning an iron regulated metal transporter from rice. J Exp Bot 53:1677-1682. doi:10.1093/jxb/erf004

Cataldo DA, Mcfadden KM, Garland TR, Willdung RE (1988) Organic constituents and complexation of nickel (II), iron (III), cadmium (II), and plutonium (IV) in soybean xylem exudates. Plant Physiol 86:734-739. doi:10.1104/pp. 86.3.734

Chérif M, Audebert A, Fofana M, Zouzou M (2009) Evaluation of iron toxicity on lowland irrigated rice in West Africa. Tropicultura 27:88-92

Chomczynski P, Sacchi N (1987) Single-step method of RNA isolation by acid guanidinium thiocyanatephenol-chloroform extraction. Anal Biochem 162:156159. doi:10.1006/abio.1987.9999

Cordeiro ACC, Medeiros RD (2008) Cultivares de Arroz Irrigado Recomendadas para Roraima. Embrapa, Roraima, pp 1-12

Counce P, Keisling TC, Mitchell AJ (2000) A uniform, objective, and adaptive system for expressing rice development. Crop Sci 40:436-443. doi:10.2135/cropsci2000.402436x

Deng H, Ye ZH, Wong MH (2009) Lead, zinc and iron $\left(\mathrm{Fe}^{2+}\right)$ tolerances in wetland plants and relation to root anatomy and spatial pattern of ROL. Environ Exp Bot 65:353-362. doi:10.1016/j.envexpbot.2008.10.005

Dorlodot S, Lutts S, Bertin P (2005) Effects of ferrous iron toxicity on the growth and mineral composition of an interspecific rice. J Plant Nutr 28:1-20. doi:10.1081/PLN-200042144

Eide D, Broderius M, Fett JP, Guerinot ML (1996) A novel ironregulated metal transporter from plants identified by functional expression in yeast. Proc Natl Acad Sci 93:5624-5628. doi:10.1073/pnas.93.11.5624

Elec V, Quimio CA, Mendoza R, Sajise AGC, Beebout SEJ, Gregorio GB, Singh RK (2013) Maintaining elevated $\mathrm{Fe}^{+2}$ concentration in solution culture for the development of a rapid and repeatable screening technique for iron toxicity tolerance in rice (Oryza sativa L.). Plant Soil 372:253-264. doi:10.1007/s11104-013-1739-4
Engel K (2009) Efficiency of adaptation mechanisms of rice to diverse conditions of iron toxicity. eScholarship University of California. http://escholarship.org/uc/item/3cz2f4rj. Accessed 12 Feb 2011

Engel K, Asch F, Becker M (2012) Classification of rice genotypes based on their mechanisms of adaptation to iron toxicity. J Plant Nutr Soil Sci 175:871-881. doi: 10.1002/jpln.201100421

Fang W, Wang J, Lin C, Kao C (2001) Iron induction of lipid peroxidation and effects on antioxidative enzyme activities in rice leaves. Plant Growth Regul 35:75-80. doi:10.1023/A:1013879019368

Genty B, Briantais JM, Baker NR (1989) The relationship between the quantum yield of photosynthetic electron transport and quenching of chlorophyll fluorescence. Biochim Biophys Acta 990:87-92

Guerinot ML, Yi Y (1994) Iron: nutritious, noxious, and not readily available. Plant Physiol 104:815-820. doi: 10.1104/pp. 104.3.815

Gustafsson JP (2014) Visual MINTEQ version 3.1 Stockholm. http://www2.1wr.kth.se/English/Oursoftware/vminteq/. Accessed 8 Sept 2014

Higuchi K, Watanabe S, Takahashi M, Kawasaki S, Nakanishi H, Nishizawa NK, Mori S (2001) Nicotianamine synthase gene expression differs in barley and rice under Fe-deficient conditions. Plant J 25:159-167

Hodges DM, DeLong JM, Forney CF, Prange RK (1999) Improving the thiobarbituric acid-reactive-substances assay for estimating lipid peroxidation in plant tissues containing anthocyanin and other interfering compounds. Planta 207: 604-611. doi:10.1007/s004250050524

Inoue H, Kobayashi T, Nozoye T, Takahashi M, Kakei Y, Suzuki K, Nakazono M, Nakanishi H, Mori S, Nishizawa NK (2009) Rice OsYSL15 is an iron-regulated iron(III)-deoxymugineic acid transporter expressed in the roots and is essential for iron uptake in early growth of the seedlings. J Biol Chem 284: 3470-3479. doi:10.1074/jbc.M806042200

Ishimaru Y, Suzuki M, Tsukamoto T, Suzuki K, Nakazono M, Kobayashi T, Wada Y, Watanabe S, Matsuhashi S, Takahashi M, Nakanishi H, Mori S, Nishizawa NK (2006) Rice plants take up iron as an $\mathrm{Fe}^{3+}$-phytosiderophore and as $\mathrm{Fe}^{2+}$. Plant $\mathrm{J}$ 45:335-346. doi:10.1111/j.1365-313X.2005.02624.x

Ishimaru $\mathrm{Y}$, Masuda $\mathrm{H}$, Bashir $\mathrm{K}$, Inoue $\mathrm{H}$, Tsukamoto $\mathrm{T}$, Takahashi M, Nakanishi H, Aoki N, Hirose T, Ohsugi R, Nishizawa NK (2010) Rice metal-nicotianamine transporter, OSYSL2, is required for the long-distance transport of iron and manganese. Plant J 62:379-390. doi:10.1111/j.1365313X.2010.04158.X

Karnovsky MJ (1965) A formaldehyde-glutaraldehyde fixative of high osmolality for use in electron microscopy. J Cell Biol 27:136-137

Khandpur RS (2005) Printed circuit boards: design, fabrication, assembly and testing. Tata McGraw-Hill, New Delphi

Kitajima M, Butler WL (1975) Quenching of chlorophyll fluorescence and primary photochemistry in chloroplasts by dibromothymoquinone. Biochim Biophys Acta 376:105-115

Lahner B, Gong T, Mahmoudian M, Smith EL, Abid KB, Rogers EE, Guerinot ML, Harper IF, Ward JM, Meintyre L, Schroeder JI, Salt DE (2003) Genomic scale profiling of nutrients and trace elements in Arabidopsis thaliana. Nat Biotechnol 21:1215-1225. doi:10.1038/nbt865 
Liu H, Zhang J, Christiec P, Zhang F (2008) Influence of iron plaque on uptake and accumulation of $\mathrm{Cd}$ by rice (Oryza sativa L.) seedlings grown in soil. Sci Total Environ 394: 361-368. doi:10.1016/j.scitotenv.2008.02.004

Majerus V, Bertin P, Lutts S (2007a) Effects of iron toxicity on osmotic potential, osmolytes and polyamines concentrations in the African rice (Oryza glaberrima Steud.). Plant Sci 173: 96-105. doi:10.1016/j.plantsci.2007.04.003

Majerus V, Bertin P, Swenden V, Fortemps A, Lobréaux S, Lutts S (2007b) Organ-dependent responses of the African rice to short-term iron toxicity: ferritin regulation and antioxidative responses. Biol Plant 51:303312. doi:10.1007/s10535-007-0060-6

Majerus V, Bertin P, Lutts S (2009) Abscisic acid and oxidative stress implications in overall ferritin synthesis by African rice (Oryza glaberrima Steud.) seedlings exposed to short term iron toxicity. Plant Soil 324:253-265. doi:10.1007/s11104-009-9952-x

Makino A, Miyake C, Yokota A (2002) Physiological functions of the water-water cycle (Mehler reaction) and the cyclic electron flow around PSI in rice leaves. Plant Cell Physiol 43: 1017-1026. doi:10.1093/pcp/pcf124

Mehraban P, Zadeh AA, Sadeghipour HR (2008) Iron toxicity in rice (Oryza sativa L.), under different potassium nutrition. Asian J Plant Sci 7:251-259. doi:10.3923/ajps.2008.251.259

Mino Y, Ishida T, Ota N, Inoue M, Nomoto K, Takemoto T, Tanaka H, Sugiura Y (1983) Mugineic acid-iron (III) complex and its structurally analogous cobalt(III) complex: characterization and implication for absorption and transport of iron in gramineous plants. J Am Chem Soc 105:4671-4676. doi:10.1021/ja00352a024

Mukherjee I, Campbell NH, Ash JS, Connolly EL (2006) Expression profiling of the Arabidopsis ferric chelate reductase (FRO) gene family reveals differential regulation by iron and copper. Planta 223:1178-1190. doi:10.1007/s00425005-0165-0

Nenova VR (2009) Growth and photosynthesis of pea plants under different iron supply. Acta Physiol Plant 31:385-391. doi:10. 1007/s11738-008-0247-2

O’Brien TP, Feder N, McCully ME (1964) Polychromatic staining of plant cell walls by toluidine blue. Protoplasma 29:368373. doi:10.1007/BF01248568

Olaleye AO, Tabi FO, Ogunkunle AO, Singh BN, Sahrawat KL (2001) Effect of toxic iron concentrations on the growth of lowlands rice. J Plant Nutr 24:441-457. doi:10.1081/PLN100104971

Oliveira IC, Brears T, Knight TJ, Clark A, Coruzzi GM (2012) Overexpression of cytosolic glutamine synthetase. Relation to nitrogen, light, and photorespiration. Plant Physiol 129: 1170-1180. doi:10.1104/pp. 020013

Onaga G, Edema R, Asea G (2013) Tolerance of rice germplasm to iron toxicity stress and the relationship between tolerance, $\mathrm{Fe}^{+2}, \mathrm{P}$ and $\mathrm{K}$ content in the leaves and roots. Arch Agron Soil Sci 59:213-229. doi:10.1080/03650340.2011.622751

Peng XX, Yamauchi M (1993) Ethylene production in rice bronzing leaves induced by ferrous iron. Plant Soil 149:227-234. doi:10.1007/BF00016613

Pereira EG, Oliva MA, Rosado-Souza L, Mendes GC, Colares DS, Stopato CH, Almeida AM (2013) Iron excess affects rice photosynthesis through stomatal and non-stomatal limitations. Plant Sci 201-202:81-92. doi:10.1016/j.plantsci. 2012.12.003
Pereira EG, Oliva MA, Siqueira-Silva AI, Rosado-Souza L, Pinheiro DT, Almeida AM (2014) Tropical rice cultivars from lowland and upland cropping systems differ in iron plaque formation. J Plant Nutr 37:1373-1394. doi:10.1080/ 01904167.2014.888744

Quinet M, Vromman D, Clippe A, Bertin P, Lequeux H, Dufey I, Lutts S, Lefevre I (2012) Combined transcriptomic and physiological approaches reveal strong differences between shortand long-term response of rice (Oryza sativa) to iron toxicity. Plant Cell Environ 35:1837-1859. doi:10.1111/j.1365-3040. 2012.02521.x

Robinson NJ, Proctor CM, Connolly EL, Guerinot ML (1999) A ferric-chelate reductase for iron uptake from soils. Nature 397:694-697. doi:10.1038/17800

Sahrawat KL (2005) Managing iron toxicity in lowland rice: the role of tolerant genotypes and plant nutrients. In: Toriyama $\mathrm{K}$, Heong KL, Hardy B (eds) Rice is life: scientific perspectives for the 21 st century, 1st edn. IRRI, Tsukuba, pp 452454

Sahrawat KL (2010) Reducing iron toxicity in lowland rice with tolerant genotypes and plant nutrition. Plant Stress 4:70-75

Saikia T, Baruah KK (2012) Iron toxicity tolerance in rice (Oryza sativa) and its association with anti-oxidative enzyme activity. J Crop Sci 3:90-94

Santana BV, de Araújo TO, Andrade GC, de Freitas-Silva L, Kuki KN, Pereira EG, Azevedo AA, da Silva LC (2014) Leaf morphoanatomy of species tolerant to excess iron and evaluation of their phytoextraction potential. Environ Sci Pollut Res Int 21:2550-2562. doi:10.1007/s11356-013-2160-5

Silveira VC, Oliveira AP, Sperotto RA, Amaral L, Dias JF, Cunha JB, Fett JP (2007) Influence of iron on mineral status of two rice (Oryza sativa L.) cultivars. Braz J Plant Physiol 19:127139. doi:10.1590/S1677-04202007000200005

Silveira VC, Fadanelli C, Sperotto RA, Stein RJ, Basso LA, Vaz Junior IS, Dias JF, Fett JP (2009) Role of ferritin in the rice tolerance to iron overload. Sci Agric 66:549-555. doi:10. 1590/S0103-90162009000400019

Smirnoff N (2005) Ascorbate, tocopherol and carotenoids: metabolism, pathway engineering and functions. In: Smirnoff $\mathrm{N}$ (ed) Antioxidants and reactive oxygen species in plants, $1 \mathrm{st}$ edn. Blackwell Publishing Ltd, Oxford, pp 53-86

Snowden R, Wheeler BD (1995) Chemical changes in selected wetland plant species with increasing Fe supply, with specific reference to root precipitates and Fe tolerance. New Phytol 131:503-520. doi:10.1111/j.1469-8137.1995.tb03087.x

Soares AA, Cornélio VMO, Soares PC, Reis MS (1997) Canastra e Confiança: cultivares melhorados de arroz para plantio em condições de sequeiro tradicional e irrigado por aspersão. Rev Ceres 44:230-240

Somers II, Shive JW (1942) The iron-manganese relation in plant metabolism. Plant Physiol 17:582-602. doi:10. 1104/pp. 17.4.582

SOSBAI (2007) Arroz Irrigado-Recomendações Técnicas da Pesquisa para o Sul do Brasil. SOSBAI, Pelotas

Stein RJ, Duarte GL, Spohr MG, Lopes SIG, Fett JP (2009a) Distinct physiological responses of two rice cultivars subjected to iron toxicity under field conditions. Ann Appl Biol 154: 269-277. doi:10.1111/j.1744-7348.2008.00293.x

Stein RJ, Ricachenevsky FK, Fett JP (2009b) Differential regulation of the two rice ferritin genes (OsFER1 and OsFER2). Plant Sci 177:563-569. doi:10.1016/j.plantsci.2009.08.001 
Suh HJ, Kim CS, Lee JY, Jung J (2002) Photodynamic effect of iron excess on photosystem II function in pea plants. Photochem Photobiol 75:513-518

Tanaka A, Navasero SA (1966) Interaction between iron and manganese in the rice plant. Soil Sci Plant Nutr 12:29-33. doi:10.1080/00380768.1966.10431958

Tanaka A, Loe R, Navasero SA (1966) Some mecanisms involved in the development of iron toxicity symptoms in the Rice plant. Soil Sci Plant Nutr 12:32-38. doi:10.1080/00380768. 1966.10431951

Taylor GJ, Crowder AA, Rodden R (1984) Formation and morphology of an iron plaque on the roots of Typha latifolia $\mathrm{L}$. grown in solution culture. Am J Bot 71:666-675

Weng XY, Zheng CJ, Xu HX, Sun JY (2007) Characteristics of photosynthesis and functions of the water-water cycle in rice (Oryza sativa) leaves in response to potassium deficiency. Physiol Plant 131: 614-621. doi:10.1111/j.1399-3054.2007.00978.x

Wilson A, Boulay C, Wilde A, Kerfeld CA, Kirilovsky D (2007) Light-induced energy dissipation in iron-starved cyanobacteria: roles of OCP and IsiA proteins. Plant Cell 19:656-672. doi:10.1105/tpc.106.045351

Wingler A, Lea PJ, Quick WP, Leegood RC (2000) Photorespiration: metabolic pathways and their role in stress protection. Philos Trans R Soc Lond B Biol Sci 355:15171529. doi:10.1098/rstb.2000.0712

Wu L-B, Shhadi MY, Gregorio G, Matthus E, Becker M, Frei M (2014) Genetic and physiological analysis of tolerance to acute iron toxicity in rice. Rice 7:8. doi:10.1186/s12284014-0008-3

Yang X, Huang J, Jiang Y, Zhang HS (2009) Cloning and functional identification of two members of the ZIP (Zrt, Irt-like protein) gene family in rice (Oryza sativa L.). Mol Biol Rep 36:281-287. doi:10.1007/s11033-007-9177-0

Yokosho K, Yamaji N, Ueno D, Mitani N, Ma JF (2009) OsFRDL1 is a citrate transporter required for efficient translocation of iron in rice. Plant Physiol 149:297-305. doi:10. 1104/pp. 108.128132

Zhang X, Zhang F, Mao D (1999) Effect of iron plaque outside roots on nutrient uptake by rice (Oryza sativa L.): phosphorus uptake. Plant Soil 209:187-192. doi:10.1023/A:1004505431879

Zhang Y, Zheng GH, Liu P, Song JM, Xu GD, Cai MZ (2011) Morphological and physiological responses of root tip cells to $\mathrm{Fe}^{2+}$ toxicity in rice. Acta Physiol Plant 33:683-689. doi: 10.1007/s11738-010-0590-y

Zhao S, Fernald RD (2005) Comprehensive algorithm for quantitative real-time polymerase chain reaction. J Comput Biol 12: 1045-1062. doi:10.1089/cmb.2005.12.1047 